\title{
Electrochemical Oxidation of Quercetin in Hydro-Alcoholic Solution
}

\author{
Ana K. Timbola, ${ }^{*}$ Cristine D. de Souza, Cristiano Giacomelli and Almir Spinelli \\ Departamento de Química, Universidade Federal de Santa Catarina, 88040-900 Florianópolis-SC, Brazil
}

\begin{abstract}
O comportamento eletroquímico da quercetina em meio hidro-alcoólico foi estudado na faixa de $\mathrm{pH}$ 2,2-9,2 aplicando-se as técnicas voltametria cíclica, eletrólise com potencial controlado e espectroscopia UV-Vis. Voltamogramas cíclicos para a quercetina mostraram três picos de oxidação e um pico de redução dependente das condições experimentais. Um processo de oxidação envolvendo dois prótons e dois elétrons no primeiro pico conduziu à formação da orto-quinona correspondente, a qual é uma espécie eletroquimicamente ativa e instável, como evidenciado pela dependência do perfil dos voltamogramas cíclicos com a velocidade de variação de potencial, em concordância com um mecanismo do tipo eletroquímico-químico (EC). Eletrólises com potencial controlado geraram três produtos caracterizados por espectroscopia UV-Vis. Um esquema reacional envolvendo as etapas eletroquímica e química foi proposto para a eletro-oxidação da quercetina em solução hidro-alcoólica, com base em dados obtidos da literatura e em evidências experimentais.
\end{abstract}

The electrochemistry of quercetin hydro-alcoholic solutions of $\mathrm{pH} 2.2$ to 9.2 was studied by cyclic voltammetry, controlled-potential electrolysis and UV-Vis spectroscopy. Cyclic voltammograms for quercetin showed three oxidation peaks and one reduction peak depending on the experimental conditions. The two-electron two-proton oxidation process at the first peak led to the formation of the corresponding ortho-quinone, which is an electrochemically active and unstable species, as evidenced by the dependence of the cyclic voltammogram profile on the applied scan rate, in agreement with the EC mechanism. Controlled-potential electrolysis yielded three products as characterized by UV-Vis spectroscopy. A reaction scheme comprising electrochemical and chemical steps was proposed for the electro-oxidation of the quercetin in hydro-alcoholic solutions on basis of experimental evidences obtained in this work and elsewhere.

Keywords: antioxidants, quercetin, electrochemistry, UV-Vis spectroscopy

\section{Introduction}

Flavonoids are among widely distributed secondary products found in many plants used as food..$^{1-3}$ There is a considerable amount of epidemiological evidences associating rich diets in fresh fruits and vegetables to lower risks of suffering from cardiovascular conditions and certain types of cancer. ${ }^{4}$ Pharmacological studies have demonstrated that some phenolic compounds possess antiinflammatory, antiviral and antifungal properties as well as an antiproliferative effect on tumor cells. ${ }^{5}$ Several of these biological effects are related to radical scavenging (antioxidant) properties of such compounds. ${ }^{3,6,7}$ Radical reactions occur in many biological processes as a natural consequence of living in an oxidizing environment. However damaging radical reactions outcome when an

*e-mail: ankati@qmc.ufsc.br unusual process takes place. ${ }^{7}$ Interesting reports on the role of free radicals and antioxidants were given by Thomas $^{6}$ and Wolf et al. ${ }^{7}$

Quercetin (3,3', 4',5,7-pentahydroxy-flavone, Figure 1 ), is a flavonoid of widespread occurrence in nature whose medicinal properties have been extensively demonstrated in the literature, especially the antioxidant capacity. ${ }^{8-11}$ The antioxidant properties of these compounds (flavonoids) have been attributed to their capacity to<smiles></smiles>

Figure 1. Chemical structure of quercetin $\left(3,3^{\prime}, 4^{\prime}, 5,7\right.$-pentahydroxy-flavone). 
scavenge free radicals generated in aqueous phase, increasing the resistance of lipids against peroxidation. ${ }^{11}$ Despite this, the electrochemical behavior of quercetin has been almost always studied in organic solvents due to constrains imposed by its solubility characteristics. Evidently, the stability of intermediate species originated by oxidation reactions is substantially different depending on the surroundings (organic or aqueous media), ${ }^{12}$ offering a very rich chemistry as consequence. In this framework, the knowledge of its electrochemical behavior in biological-like conditions is relevant to get insight into the quercetin action as antioxidant.

To date, few information on the electrochemical properties of flavonoids in aqueous solutions are found in the literature. ${ }^{13}$ The electrochemistry of quercetin, in particular, besides not being very understood, reveals contradictions on both the oxidation products and the reversibility of the reactions. For instance, a limited extent of data available in the pertinent literature suggests that the oxidation of quercetin yields to the corresponding ortho-quinone as product, which is an unstable compound that could undergo homogeneous chemical reactions such as intramolecular rearrangements ${ }^{13-16}$ or addition reactions when in presence of nucleophiles. ${ }^{17}$ Therefore, the presence of water and/or ethanol (nucleophiles) in the solution may thus have very important implications for the oxidation mechanism and in turn for the antioxidant activity, since water was found to act as catalysts in reactions subsequent to the formation of ortho-quinones. ${ }^{15}$

The objectives of this work are to study the electrochemical behavior of quercetin in hydro-alcoholic solution of $\mathrm{pH} 2.2$ to 9.2 , to characterize the oxidation products and to propose a reaction scheme in order to gain insight into the antioxidant and electrochemical properties of this important flavonoid.

\section{Experimental}

\section{Chemicals}

All reagents used in this study were of analytical grade acquired from Fluka (quercetin), Grupo Química (ethanol), FMaia (acetone, ethyl acetate and hexane), and Merck $\left(\mathrm{H}_{3} \mathrm{PO}_{4}, \mathrm{~K}_{2} \mathrm{HPO}_{4}, \mathrm{KH}_{2} \mathrm{PO}_{4}\right.$ and $\left.\mathrm{KOH}\right)$. They were used without previous purification. Distilled and deionized water was used for all solution preparations.

\section{Cyclic voltammetry}

Cyclic voltammograms were obtained in a $15 \mathrm{~mL}$ three electrode cell, with a $3.0 \mathrm{~mm}$ diameter glassy carbon working electrode (BAS MF-2012), a graphite rod counter electrode and a saturated calomel reference electrode (SCE). All potentials in the text are quoted versus this reference electrode. The results were obtained with an EG \& G PAR model 263A potentiostat/galvanostat and the M270/250 software coupled to a personal computer. The working electrode was carefully polished before each experiment with $0.05 \mu \mathrm{m}$ alumina paste and ultrasonically rinsed in deionized water. Solutions containing ethanol and $\mathrm{K}_{2} \mathrm{HPO}_{4} /$ $\mathrm{KH}_{2} \mathrm{PO}_{4}$ (both $0.05 \mathrm{~mol} \mathrm{~L}^{-1}$ ) 1:1 (v/v) with $\mathrm{pH}$ adjusted with $\mathrm{KOH}$ or $\mathrm{H}_{3} \mathrm{PO}_{4}$ to the studied values $(2.2 ; 4.4 ; 6.4$; $7.4 ; 8.4 ; 9.2)$ were used as supporting electrolyte. Quercetin was added directly to the cell (final concentration $0.8 \mathrm{mmol}$ $\mathrm{L}^{-1}$ ) after obtaining a cyclic voltammogram of the electrode immersed in the quercetin-free solution. The solutions were purged with nitrogen for eight minutes before recording the voltammograms, and the experiments were carried out at room temperature. Cyclic voltammograms were also obtained by setting the switching positive potential at 0.05 $\mathrm{V}$ after the first oxidation process in order to study the reversibility of the reaction that takes place at peak I.

\section{Controlled-potential electrolysis and characteristics of oxidation products}

Controlled-potential electrolysis experiments were performed to determine the number of electrons transferred and to characterize the products formed in the first electrooxidation process (peak I). In a typical procedure, $80 \mathrm{~mL}$ of a $2.0 \mathrm{mmol} \mathrm{L}^{-1}$ quercetin hydro-alcoholic solution at $\mathrm{pH} 4.4$ were electrolyzed at $0.8 \mathrm{~V}$ in a two-compartment cell. The working electrode used in the controlled-potential electrolysis was an assembly consisting of three carbon rods $(6 \mathrm{~mm}$ diameter and $6 \mathrm{~cm}$ lengh) and a carbon rod as the auxiliary electrode. The reference was a saturated calomel electrode (SCE). The electrolysis was interrupted each $15 \mathrm{~min}$ to reactivate the working electrode by washing it with acetone. After the electrolysis, the solution was kept in a refrigerator $\left(\sim 2{ }^{\circ} \mathrm{C}\right)$ during 96 hours. Then, the electrolyzed solution was filtered to remove solid products, and the remaining solution was evaporated (purification step). Thin layer chromatography (TLC) of the resulting oil revealed the presence of five spots (quercetin and others more polar compounds). The compounds present in this oily solution were chromatographically separated in a silica column using mixtures of hexane/ethyl acetate from 100:0 to 0:100 (v/v) as eluent. Twenty-four fractions were thus collected and re-analyzed by TLC. More representative fractions were examined by UV-Vis spectroscopy (Hitachi U-3000). The yield of this purification process was very low, and therefore further spectroscopic analyses were not performed. 


\section{Results and Discussion}

\section{Cyclic voltammetry}

Figure 2 shows a typical cyclic voltammogram at a glassy carbon electrode immersed in hydro-alcoholic solution 1:1 $(\mathrm{v} / \mathrm{v})$ at $\mathrm{pH} 7.4$ containing $0.8 \mathrm{mmol} \mathrm{L}^{-1}$ quercetin for a scan rate $(v)$ of $100 \mathrm{mV} \mathrm{s}^{-1}$. In these experimental conditions, three oxidation processes (peaks I, II and III) are observed at +0.15 $\mathrm{V}\left(\mathrm{E}_{\mathrm{pa}}{ }^{\mathrm{I}}\right),+0.46 \mathrm{~V}\left(\mathrm{E}_{\mathrm{pa}}{ }^{\mathrm{II}}\right)$ and $+0.88 \mathrm{~V}\left(\mathrm{E}_{\mathrm{pa}}{ }^{\mathrm{III}}\right)$.

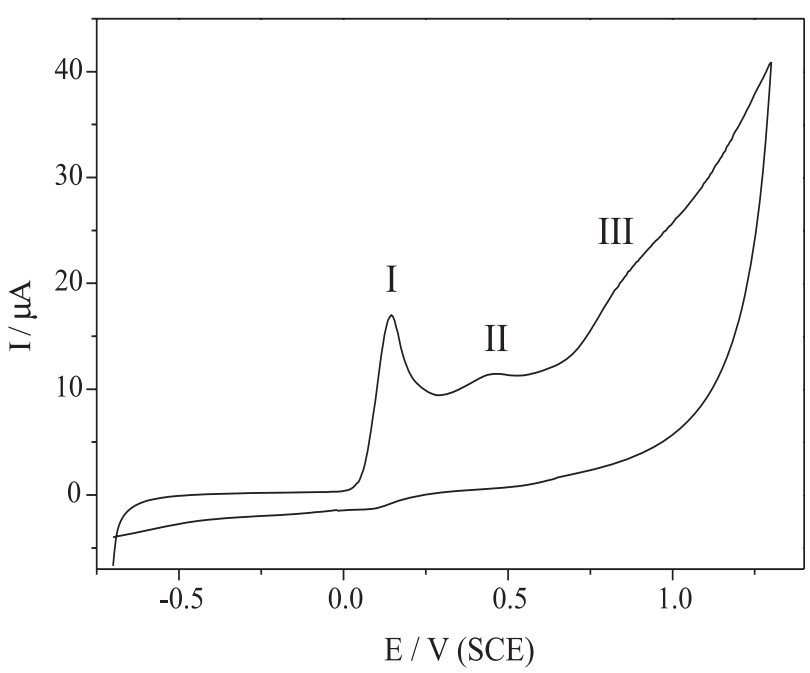

Figure 2. Cyclic voltammogram for $0.8 \mathrm{mmol} \mathrm{L}^{-1}$ quercetin in $\mathrm{pH} 7.4$ hydro-alcoholic solution at a glassy carbon electrode for $v=100 \mathrm{mV} \mathrm{s}^{-1}$.

The overall cyclic voltammogram profile is similar to those previously reported..$^{13,14,16,17}$ In general, it has been proposed that the charge transfer process at peak I corresponds to the oxidation of the 3',4'-dihydroxy substitute on B-ring of quercetin, while the peaks II and III comprise oxidation reactions involving the hydroxyl group at C-3 and the 5,7-dihydroxy substitutes on A-ring, respectively. Depending on the experimental conditions, the corresponding reduction reactions were evidenced (see below). The difficulties to isolate the oxidation products formed in each particular oxidation peak and the chemical reactivity associated to some of them have not allowed a straightforward establishment of a reaction scheme. ${ }^{18,19}$ Besides, there still exists controversies on the reversibility of reactions occurring in these oxidation processes.

Depending on the characteristics of each particular electrochemical system, the scan rate effect on the cyclic voltammetric profile is an important tool to evaluate the presence of homogenous chemical reactions perhaps following the electrochemical ones. ${ }^{20}$ We have thus firstly investigated the influence of the scan rate $(v)$ in order to access in more details the characteristics of electrochemical and chemical reactions taking place at the electrode/solution interface. On basis of the results shown hereinafter, we suggest a slightly different interpretation for the oxidation of quercetin, mainly with respect to the electrochemical and chemical processes occurring around the first peak.

\section{Influence of scan rate}

Figure 3 shows the influence of scan rate $(v)$ on the voltammetric profile of $0.8 \mathrm{mmol} \mathrm{\textrm {L } ^ { - 1 }}$ quercetin in hydroalcoholic solution at $\mathrm{pH}$ 7.4. These voltammograms show that the first oxidation process (peak I) is practically independent on $v$, whereas peaks II and III become more accentuated with the increase in $v$. While for $v=10 \mathrm{mV}$ $\mathrm{s}^{-1}$ the peaks II and III are not present, for $v=100 \mathrm{mV} \mathrm{s}^{-1}$ these charge transfer processes are clearly evidenced. This behavior suggests that the appearance of peaks II and III depends on the experimental time scale. A plausible interpretation for the differences observed in Figure 3 is that at peak I an electrochemically active and unstable product is formed, which can be further oxidized at peak II when the elapsed time of analysis after its generation is sufficiently short (i.e., faster scan rate). The same comments also apply for peak III.

Cyclic voltammograms profiles with dependence on $v$ suggest the occurrence of homogeneous chemical reactions following the charge transfer one according to an EC mechanism. ${ }^{21}$ Therefore, our findings indicate the existence of EC mechanisms at peaks I and II. Besides, the results reveal that the oxidation processes at peaks II and III do not correspond to the oxidation of the hydroxyl group present in C-3 and of the substitute 5,7-dihydroxy (A-ring), respectively, as suggested by some authors. ${ }^{13,14,17}$ If it was the case, the peaks II and III would not be dependent on $v$,

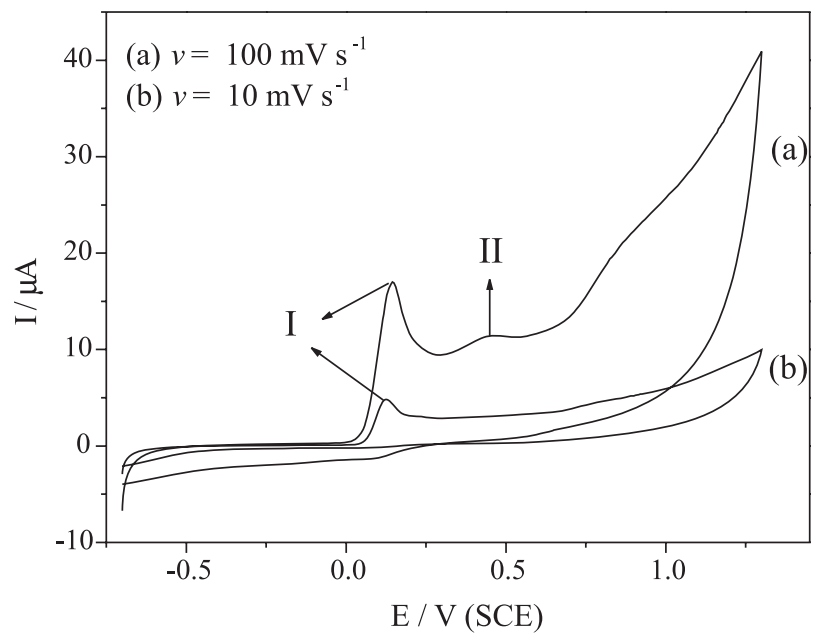

Figure 3. Cyclic voltammograms for $0.8 \mathrm{mmol} \mathrm{L}^{-1}$ quercetin in $\mathrm{pH} 7.4$ hydro-alcoholic solution at a glassy carbon electrode for (a) 100 and (b) $10 \mathrm{mV} \mathrm{s}^{-1}$. 
because the reactions would happen regardless of the time of analysis. Furthermore, a reduction peak (IV) associated to peak I was found to be dependent on $v$ (see below).

Figure 4 shows the influence of scan rate $(v)$ on the voltammetric profile $\left(\mathrm{E}_{\lambda, \mathrm{c}}=-0.70 \mathrm{~V}\right.$ e $\mathrm{E}_{\lambda, \mathrm{a}}=\left(\mathrm{E}_{\mathrm{pa}}{ }^{\mathrm{I}}+0.05\right) \mathrm{V}$ vs $\mathrm{SCE}$ ) of $0.8 \mathrm{mmol} \mathrm{L}^{-1}$ quercetin in hydro-alcoholic solution at $\mathrm{pH}$ 7.4. Under these experimental conditions, it was verified the presence of a reduction peak IV, which is correlated to the oxidation peak I. Upon increasing the scan rate $(v)$ there occurs a shift in $\mathrm{E}_{\mathrm{pa}}^{\mathrm{I}}$ towards more positives values, meanwhile $\mathrm{E}_{\mathrm{pc}}^{\mathrm{IV}}$ shifts towards less positives values, as well as a visible augmentation in the current densities. As depicted in the inset of Figure 4, the current ratio $\mathrm{I}_{\mathrm{pc}}^{\mathrm{IV}} / \mathrm{I}_{\mathrm{pa}}^{\mathrm{I}}$ progressively increases as a function of $v$, corroborating an EC-type mechanism ${ }^{21}$ associated to peak I as mentioned above.

The same approach was also applied to peaks II and III, however no additional reduction processes were found, likely due to either high instability or electrochemically inactivity of electro-generated products.

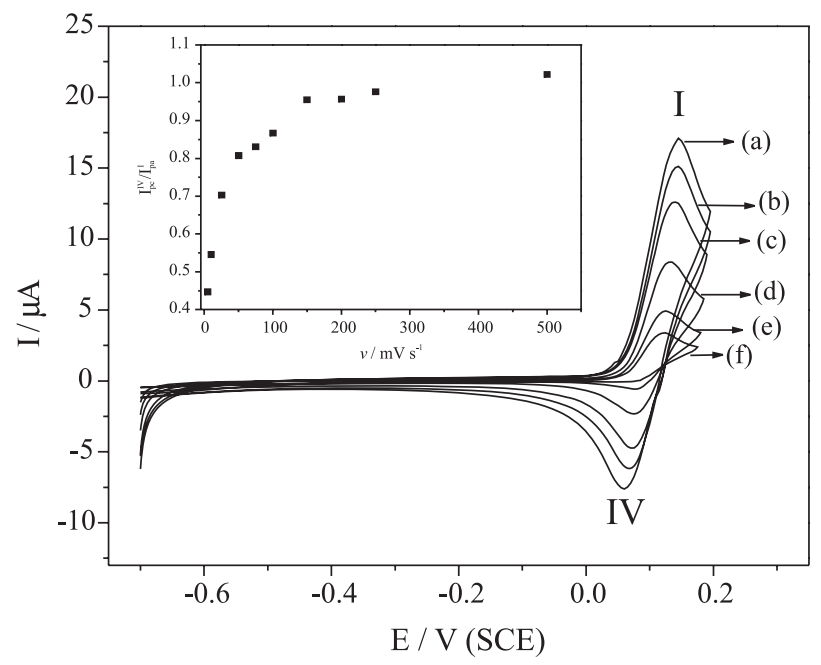

Figure 4. Cyclic voltammograms for $0.8 \mathrm{mmol} \mathrm{L}^{-1}$ quercetin in $\mathrm{pH} 7.4$ hydro-alcoholic solution at a glassy carbon electrode for (a) 5; (b) 10; (c) 25; (d) 50; (e) 75 and (f) $100 \mathrm{mV} \mathrm{s}^{-1}$. Inset: $\mathrm{I}_{\mathrm{pc}}^{\mathrm{IV}} / \mathrm{I}_{\mathrm{pa}}^{\mathrm{I}}$ ratio as a function of scan rate.

\section{Influence of $p H$}

The influence of $\mathrm{pH}$ on the cyclic voltammograms at a glassy carbon electrode immersed in $0.8 \mathrm{mmol} \mathrm{L}^{-1}$ quercetin hydro-alcoholic solutions for $v=100 \mathrm{mV} \mathrm{s}^{-1}$ is shown in Figure 5. In this illustration, it can be verified that the proton concentration produces significant changes in the voltammetric profile of quercetin, indicating that there exists an effective participation of $\mathrm{H}_{3} \mathrm{O}^{+}$ions in the electro-oxidative mechanism in all steps (peaks I, II and III). Firstly, the potential of peak I ( $\mathrm{E}_{\mathrm{pa}}^{\mathrm{I}}$ ) markedly decreases with the increase in the solution $\mathrm{pH}$.

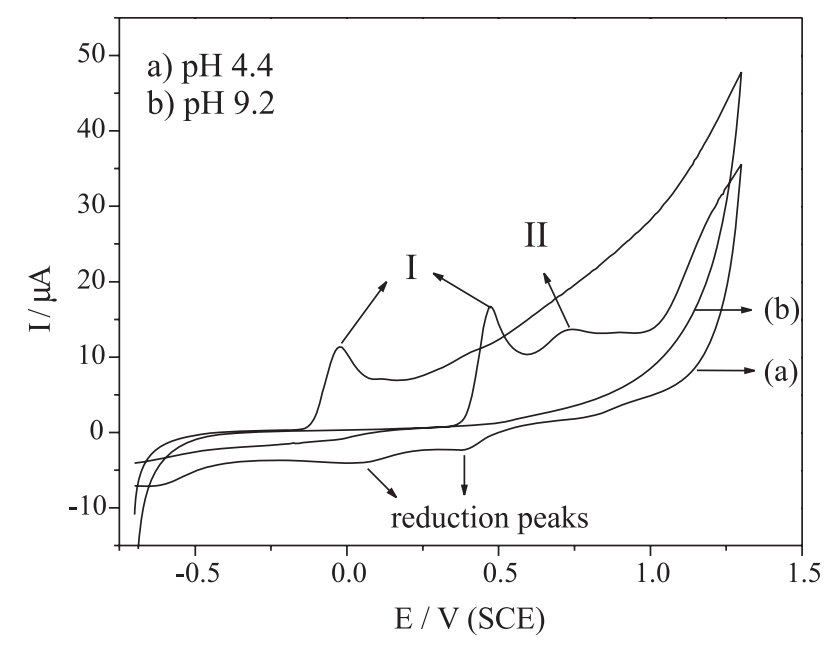

Figure 5. Cyclic voltammograms for $0.8 \mathrm{mmol} \mathrm{L}^{-1}$ quercetin in $\mathrm{pH}$ (a) 4.4 and (b) 9.2 hydro-alcoholic solution at a glassy carbon electrode for $v=100 \mathrm{mV} \mathrm{s}^{-1}$.

Meanwhile, the electrochemical processes pointed by peaks II and III at low $\mathrm{pH}$, disappear at high $\mathrm{pH}$ conditions. The dependence of $\mathrm{E}_{\mathrm{pa}}{ }^{\mathrm{I}}$ on the solution $\mathrm{pH}$ generates a straight line (Figure 6) whose slope is -61.45 $\mathrm{mV} \mathrm{pH}^{-1}(\mathrm{r}=-0.9998)$. This slope has been usually determined for phenolics systems in aqueous media, ${ }^{20}$ which stands for electrochemical reactions followed by deprotonation involving the same number of electrons (n) and protons $(\mathrm{m})$. It is interesting to note that even though the system under investigation is not fully electrochemical reversible, the slope of the graphic $\mathrm{E}_{\mathrm{pa}}{ }^{\mathrm{I}}$ $\mathrm{x} \mathrm{pH}$ is very close to that expected for Nernstian conditions (i.e., fast and reversible electron transfers, where $\mathrm{E}=\mathrm{K}-0,0592 \mathrm{pH}$ at $298 \mathrm{~K}, \mathrm{n}=\mathrm{m}$ and $\mathrm{K}$ is a constant).

As it will be shown below (controlled-potential electrolysis and UV-Vis results), a two-electron oxidation

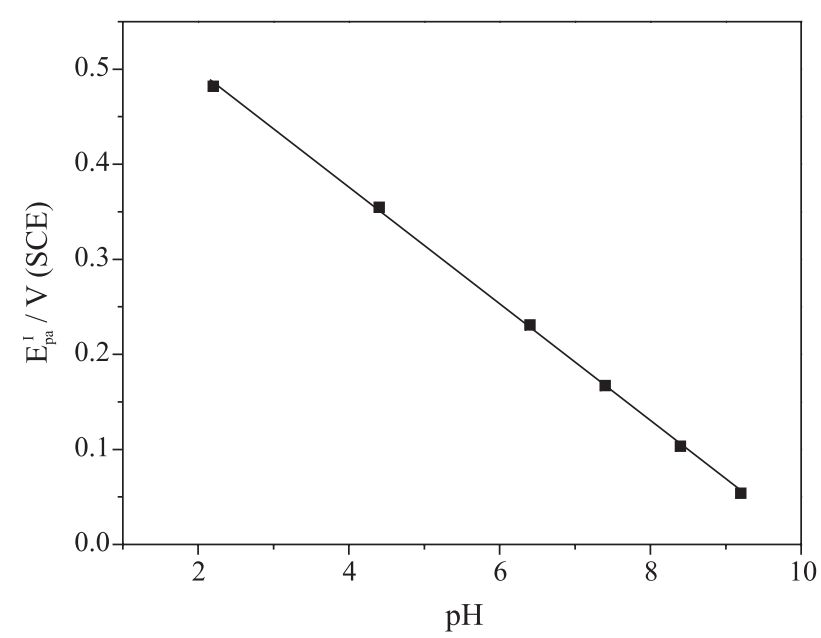

Figure 6. Anodic peak potential $\left(\mathrm{E}_{\mathrm{pa}}^{\mathrm{I}}\right)$ as a function of $\mathrm{pH}$ (data extracted from $0.8 \mathrm{mmol} \mathrm{L}^{-1}$ quercetin hydro-alcoholic solution cyclic voltammograms for $v=100 \mathrm{mV} \mathrm{s}^{-1}$ ). 
process of quercetin occurs at peak I leading to the formation of the corresponding ortho-quinone structure. It is well-known in the literature that the chemical stability of ortho-quinones is markedly influenced by the presence of nucleophiles in solution (e.g., water, ethanol, benzenesulfinic derivatives, etc). ${ }^{22}$ Considering these facts along with the experimental evidences discussed in the previous section which support an EC mechanism at peak I, we have addressed the chemical stability of electro-generated species at this peak by applying an $\mathrm{E}_{\lambda, \mathrm{a}}$ slightly higher than $\mathrm{E}_{\mathrm{pa}}^{\mathrm{I}}$.

Figure 7 shows typical influence of the solution $\mathrm{pH}$ and scan rate on the voltammetric profile of $0.8 \mathrm{mmol}$ $\mathrm{L}^{-1}$ quercetin hydro-alcoholic solutions for $v=5 \mathrm{mV}$ $\mathrm{s}^{-1}$ (Figure 7A) and $100 \mathrm{mV} \mathrm{s}^{-1}$ (Figure 7B). In this figure, it can be seen that the cathodic current corresponding to the reduction peak IV ( $\mathrm{I}_{\mathrm{pc}}^{\mathrm{IV}}$ ) clearly depends on both solution $\mathrm{pH}$ and scan rate. For $5 \mathrm{mV} \mathrm{s}^{-1}$ the peak IV is in general not clearly observed (except for $\mathrm{pH} 4.4$ and 6.4). However, upon increasing $v$ to $100 \mathrm{mV} \mathrm{s}^{-1}$ this reduction process is brought about. This scenario denotes that the product of quercetin oxidation (i.e., the corresponding electrochemically active ortho-quinone) becomes unstable under determined experimental conditions, and therefore only its partial reduction is observed, also in agreement with an EC mechanism.

\section{Controlled-potential electrolysis}

Controlled-potential electrolysis was performed in a hydro-alcoholic solution (pH 4.4) containing $2.0 \mathrm{mmol} \mathrm{L}^{-1}$ quercetin at $0.80 \mathrm{~V}(\mathrm{SCE})$. The electrolysis progress was monitored using cyclic voltammetry and UV-Vis spectroscopy. During this experiment, the formation of a browncolored compound at the electrode/solution interface was visually confirmed. Figure 8A shows cyclic voltammograms for $2.0 \mathrm{mmol} \mathrm{L}^{-1}$ quercetin (a) before the electrolysis, (b) after the consumption of 31 coulombs and (c) after the consumption of about two electrons per molecule of quercetin. Clearly, the current at peak I ( $\left.\mathrm{I}_{\mathrm{pa}}^{\mathrm{I}}\right)$ decreases proportionally to the electrolysis progress, but does not completely disappear even after the charge consumption becomes about two electrons per molecule of quercetin, suggesting that a fraction of quercetin still remains in solution. Successive tests to separate the non-electrolyzed quercetin revealed that this compound precipitates selectively at low
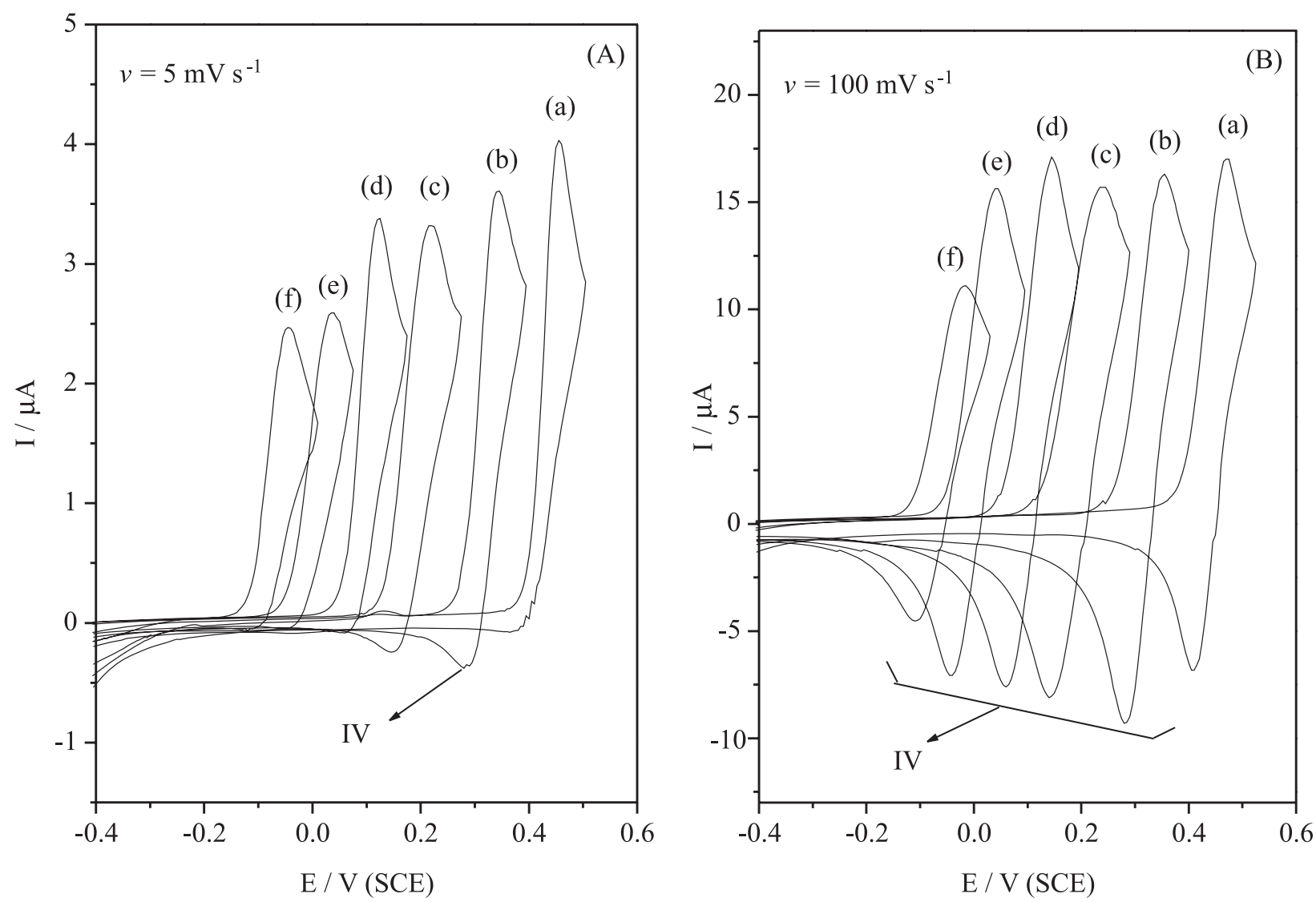

Figure 7. Cyclic voltammograms for $0.8 \mathrm{mmol} \mathrm{L}^{-1}$ quercetin in $\mathrm{pH}$ (a) 2.2, (b) 4.4, (c) 6.4, (d) 7.4, (e) 8.4 and (e) 9.2 in hydro-alcoholic solution for (A) 5 and (B) $100 \mathrm{mV} \mathrm{s}^{-1}$. 
temperature $\left(\sim 2{ }^{\circ} \mathrm{C}\right)$ after a given period of time (96 h). Thus, in a first step, quercetin was removed from the electrolyzed solution by filtration. The resulting quercetinfree solution contained a mixture of compounds whose polarity was higher than that of quercetin, as judged from thin layer chromatography (TLC) analysis.

Figure 8B shows UV-Vis spectra for quercetin (spectrum a), for the electrolyzed solution (spectrum b) and for the resulting solution after the purification step (spectrum c). Quercetin (spectrum a) exhibits two absorption bands at 257 and $373 \mathrm{~nm}$ referring to conjugations in the B-ring and A-ring, respectively. ${ }^{13-15}$ Upon electrolysis (spectrum b), a new absorption band appears around $290 \mathrm{~nm}$, while the bands at 257 and $373 \mathrm{~nm}$ exhibited lower intensities. After the purification step (spectrum c), the absorption band at $373 \mathrm{~nm}$ became less pronounced and the absorption band in $257 \mathrm{~nm}$ practically disappeared.

Special attention is hereinafter focused on the electrolyzed solution corresponding to spectrum $\mathrm{c}$ in Figure 8B. Since TLC analysis pointed out a mixture of compounds in such a case, further separation methods (column chromatography) were applied in order to purify the main components. Whereby, three principal oily fractions have been obtained (fractions A, B and C). Figure 9 exhibits the respective UV-Vis spectra along with a typical quercetin spectrum for comparison. In the spectrum shown in Figure 9A essentially two absorption bands are observed at 293 and $373 \mathrm{~nm}$. It is noteworthy to note that the typical absorption of non-oxidized quercetin at 257 $\mathrm{nm}$ disappeared, suggesting that the compound in fraction A contains distinct chromophores. In turn, this means that the electronic structure of the A-ring and B-ring of quercetin underwent modifications. The spectrum recorded for fraction B (Figure 9B) showed an absorption band at $293 \mathrm{~nm}$ and a shoulder at $321 \mathrm{~nm}$. This profile has been attributed to decreased conjugation ${ }^{13-15}$ and presence of a quinonoid structure as chromophore. ${ }^{23}$ Finally, only a single absorption band at $293 \mathrm{~nm}$ is observed in the spectrum corresponding to fraction $\mathrm{C}$ (the most polar one) (Figure 9C).

Figure 10 shows the structures of quercetin $\mathbf{I}$ and its ortho-semiquinone II, ortho-quinone III and para-quinone methides IV, $\mathbf{V}$ and VI. These reactions were described previously and have been taken into account to explain the antioxidant and pro-oxidant activities of quercetin in pharmacological researches. ${ }^{24,25}$ According to Figure 10, the oxidation of quercetin I involving the participation of one-electron and one-proton leads to the formation of the ortho-semiquinone II, which can be further oxidized in a one-electron and one-proton forming the para-quinone methide IV. The intermediate IV can subsequently turn into one of its analogous III, V or VI through tautomerization. The oxidation of quercetin $\mathbf{I}$ in a one-step two-electrons two-protons process leads directly to the formation of the ortho-quinone III, which can interconvert to the paraquinone methides IV, V and VI as shown previously.

These observations are consistent with a proposed EC mechanism for electrochemical oxidation of quercetin in hydro-alcoholic solution (Figure 11). The visualization of the detachment of a brown-colored compound at the electrode interface during the controlled potential electrolysis, and the evidences that in the first oxidation step at peak I an electronic transfer followed by deprotonation involving equal numbers of electrons and protons takes place (Figure 6), and that the charge consumed in the electrolysis was of approximately two
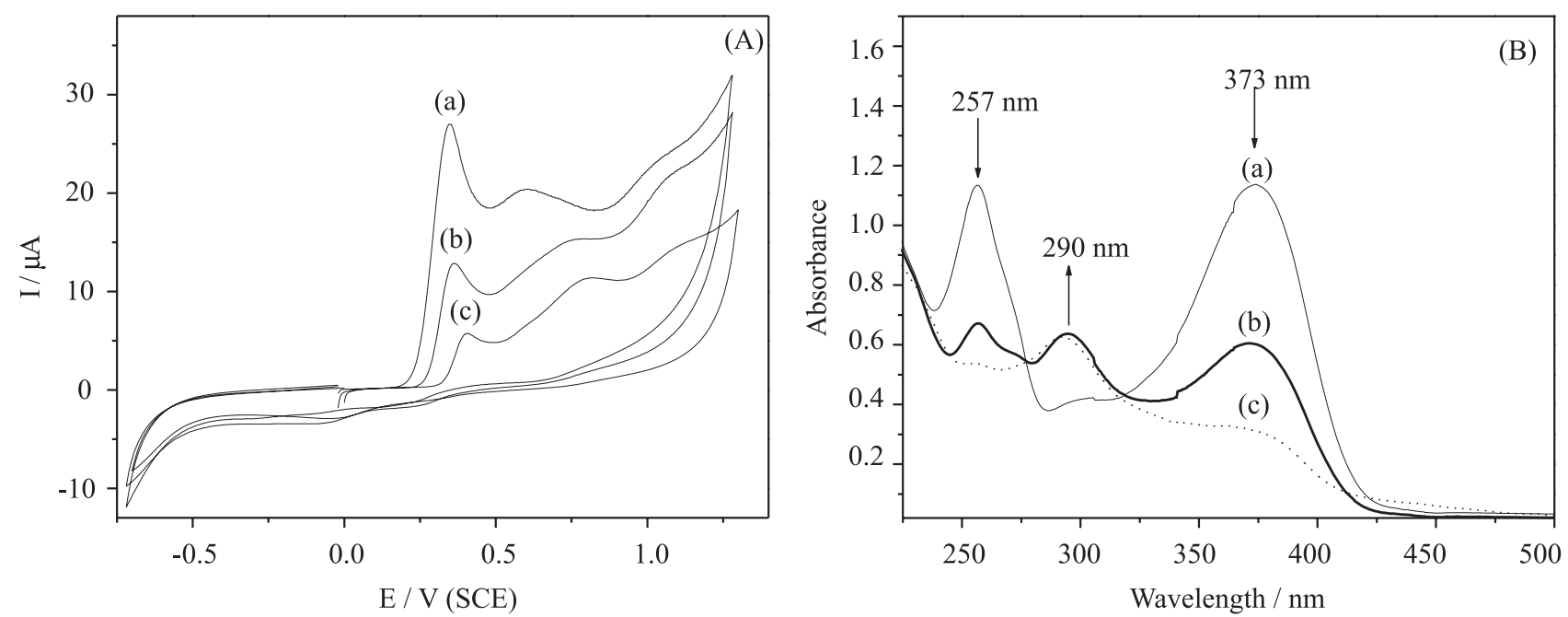

Figure 8. (A) Cyclic voltammograms for $2.0 \mathrm{mmol} \mathrm{L}^{-1}$ quercetin in $\mathrm{pH} 4.4$ hydro-alcoholic solution at a glassy carbon electrode for $v=50 \mathrm{mV} \mathrm{s}^{-1}$ and $(\mathrm{B})$ UV-vis spectra (a) before controlled-potential electrolysis, (b) after consumption of about 31 coulombs and (c) after purification step. 

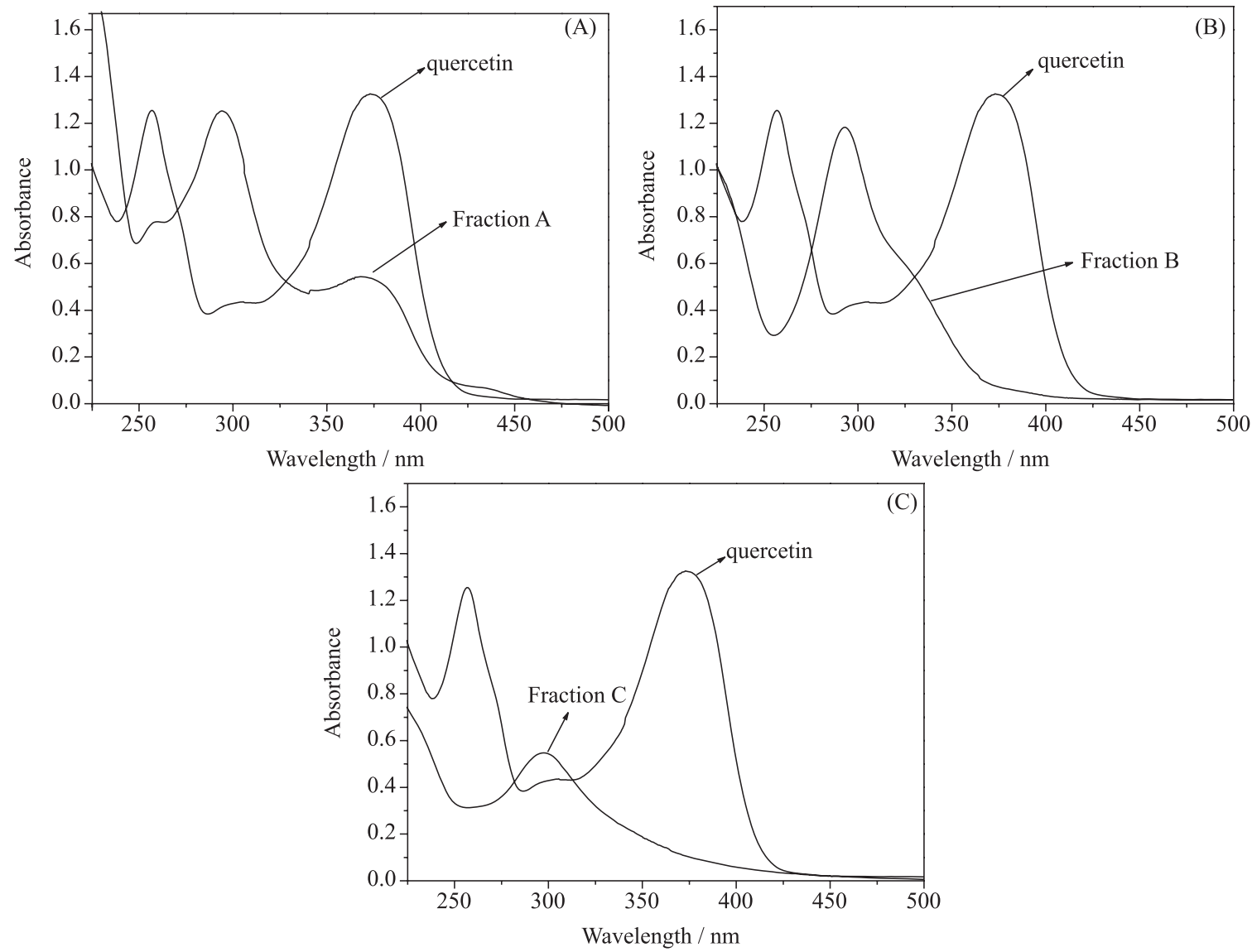

Figure 9. UV-Vis spectra for quercetin and three chromatographically-resolved fractions. (A) fraction A, (B) fraction B and (C) fraction C.

electrons per molecule (even though it for molecule of $\mathbf{I}$ ), all confirm the formation of III or its tautomers IV, $\mathbf{V}$ or VI (Figure 10).

The quinone/quinone methides species of quercetin and of other flavonoids are very unstable and undergo homogeneous chemical reactions in the sequence, the chemical step of the EC mechanism. Those reactions are fast and dependent on the solution $\mathrm{pH}$. The structure of para-quinone methide IV (Figure 11) and of quinonoid species III, V and VI (Figure 10) are very similar to the<smiles>O=c1c(O)c(-c2ccc(O)c(O)c2)oc2cc(O)cc(O)c12</smiles><smiles>COc1ccc(-c2oc3cc(O)cc(O)c3c(=O)c2O)cc1[O-]</smiles><smiles>O=C1C=C(O)c2c(O)c(=O)c(=C3C=CC(=O)C(O)=C3)oc2=C1</smiles>

quercetin

ortho-semiquinone

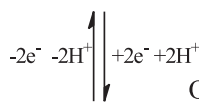<smiles>O=C1C=CC(c2oc3cc(O)cc(O)c3c(=O)c2O)=CC1=O</smiles><smiles>C#CC#C</smiles>
$+1 \mathrm{e}^{-}+1 \mathrm{H}^{+}||-1 \mathrm{e}^{-}-1 \mathrm{H}^{+}$

tho-quinone

Figure 10. Reactions sequence indicating the formation of quinone species for quercetin. 
skeleton of anthocyanins, and they exist in acid-base equilibrium with the species VII and VIII (Figure 11). In hydro-alcoholic solution, the presence of ethanol and water may thus be crucial for the fate of the quercetin, since acid as well as base, they can be acting as catalysts becoming possible the formation of IX and XII (Figure 11). We believe that due to the presence of water there occurs the formation of a hemiketal, which is in tautomeric equilibrium with $\mathbf{X}$ and $\mathbf{X I}$ (Figure 11). The spectrum suggested for chromatographically resolved fraction $\mathbf{B}$ is very similar to that described for XI. ${ }^{14,15}$

The presence of ethanol in solution can lead to the formation of XII (Figure 11) and in this case the introduction of an ethoxy group at the position $\mathrm{C} 2$ originating a ketal, excluding the possibility of ring opening which only is possible for hemiketal. ${ }^{26-28}$ However, another reaction that can be occurring after the formation of III or other quinone species of $\mathbf{I}$ is the nucleophilic attack of $\mathrm{OH}$ group in position $\mathrm{C} 3$ (C-ring) at 6'-carbon (B-ring), forming XIII (Figure 11- inset), a cyclic ether with only one $\mathrm{OH}$ regenerated at the B-ring. UV-Vis spectra of the fractions (Figure 9) are similar, indicating lost of structural conjugation in relation to chemical structure of I. The fraction $\mathbf{C}$ is more polar than $\mathbf{A}$, due the elution order in chromatographic purification. We propose the structures XII and XIII (Figure 11) for fractions $\mathbf{A}$ and $\mathbf{C}$, respectively. The addition of water and ethanol at 6'-position of the ortho-quinone III with

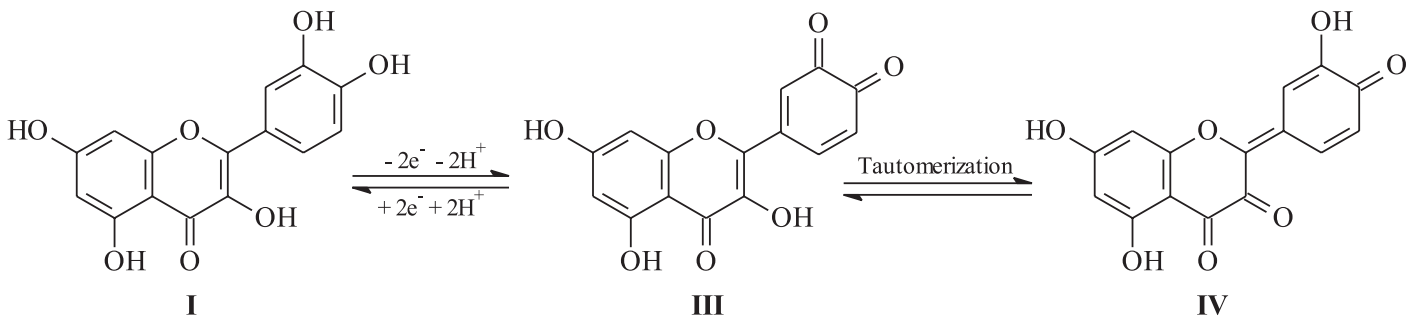<smiles>[Y1]C#CC[C@H](C)Oc1cc(O)c2c(c1)O[C@H](c1ccc(O)c(O)c1)C(=O)C2=O</smiles><smiles>C=C=C=C</smiles><smiles>CC[C+](C)[O-]</smiles><smiles>[X]C(C)(C)C(=O)c1ccc(O)c(O)c1</smiles>
$\left(\mathrm{R}=\mathbf{C H}_{3} \mathbf{C H}_{2}{ }^{-}\right)$

Fraction A

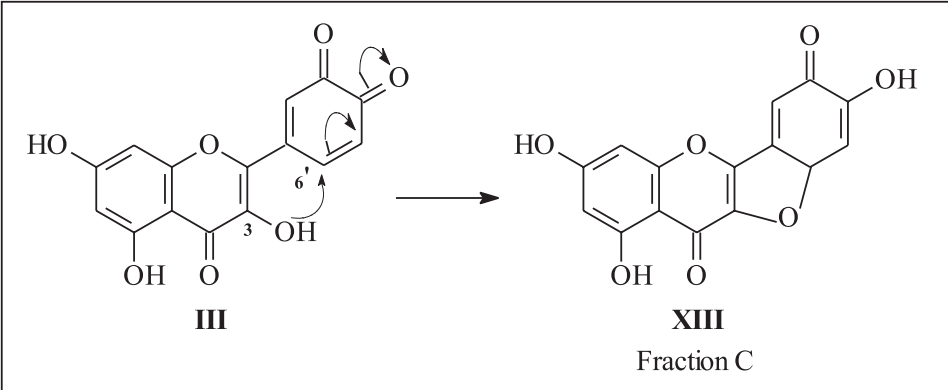

Figure 11. Reaction sequence for quercetin in hydro-alcoholic solution. 


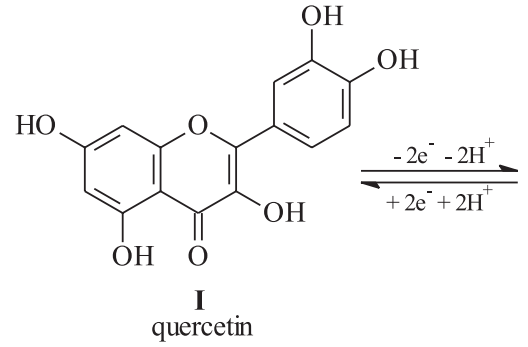<smiles>O=C1C=CC(c2oc3cc(O)cc(O)c3c(=O)c2O)=CC1=O</smiles>

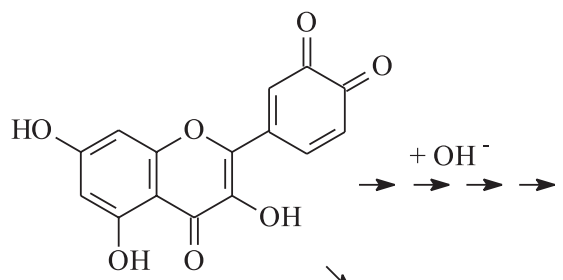

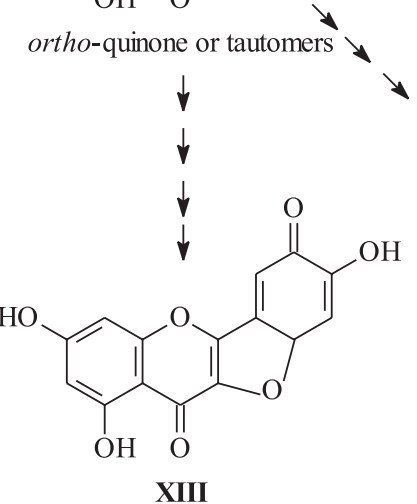<smiles>O=C1C(=O)C(O)(c2ccc(O)c(O)c2)Oc2cc(O)cc(O)c21</smiles><smiles>O=C(c1ccc(O)c(O)c1)C1(O)Oc2cc(O)cc(O)c2C1=O</smiles>

XI

Figure 12. Proposed EC mechanism for quercetin in hydro-alcoholic solution.

formation of stable derivatives were excluded because these nucleophilic attacks can lead to the formation of dimmers and trimmers presumably by a slow reaction..$^{13}$

In a simplified way, Figure 12 shows the reactions involved in the EC mechanism of the first oxidation process (peak I) of quercetin in hydro-alcoholic solution. The electrochemical step corresponds to the formation of ortho-quinone or tautomers from quercetin. In other words, this step corresponds to the oxidation of the 3',4'-dihydroxy substitute present in the B-ring of quercetin. As for chemical step, in these experimental conditions, the disappearance of the ortho-quinone formed in the electrochemical step can be associated to the parallel formation of XI, XII and/ or XIII (Figure 12) proven by UV-Vis spectra (Figure 9). It has been observed that subsequently to the first oxidation process at peak I at least three different compounds remain in solution.

\section{Conclusions}

The results presented here show that the reactions of quercetin in hydro-alcoholic solution involve several complex steps, mainly after the first oxidation peak. The quercetin $\mathbf{I}$ is electrochemically oxidized at a glassy carbon electrode in a two-protons two-electrons process. In this electrochemical step, the resultant generated electroactive ortho-quinone III or tautomers IV, $\mathbf{V}$ and/ or VI react in the bulk solution. In the chemical step the disappearance of III or IV, $\mathbf{V}$ and/or VI leads to the formation of XI, XII and/or XIII. The homogeneous chemical reactions can be catalyzed by water and ethanol, producing the three different compounds identified by UV-vis spectroscopy. The second oxidation process at peak II does not concern the hydroxyl substituent at C-3, once the C-ring of quercetin suffered significant modifications. Finally, peaks II and III are ascribed to the oxidation of by-products formed in the preceding electrochemical steps.

\section{Acknowledgments}

This work was supported by Conselho Nacional de Desenvolvimento Científico e Tecnológico (CNPq, Brazil) and Coordenação de Aperfeiçoamento de Pessoal de Nível Superior (CAPES, Brazil). 


\section{References}

1. Kikuzaki, H.; Hisamoto, M.; Hirose, K.; Akiyama, K.; Taniguchi, H.; J. Agric. Food Chem. 2002, 50, 2161.

2. Moon, J. H.; Terao, J.; J. Agric. Food Chem. 1998, 46, 5062.

3. Rice-Evans, C. A.; Miller, N. J.; Paganga, G.; Free Radical Biol. Med. 1996, 20, 933.

4. Das, D. K.; Sato, M.; Ray, P. S.; Maulik, G.; Engelman, R. M.; Berteli, A. A.; Bertelli, A.; Drug Exp. Clin. Res. 1999, 25, 115.

5. Sakagami, H.; Satoh, K.; Anticancer Res. 1997, 17, 221.

6. Thomas, M. J.; Nutrition 2000, 16, 716.

7. Wolf, R.; Wolf, D.; Ruocco, V.; J. Eur. Acad. Dermatol. Venereol. 1998, 10, 103.

8. Korkina, L. G.; Afanas'ev, I. B.; Advances in Pharmacology, Academic Press Inc: New York, 1997, vol. 38, p. 151.

9. Rice-Evans, C. A.; Packer, L.; Flavonoids in Health and Disease, Marcel Decker Inc: New York, 1998, p. 65.

10. Lemanska, K.; Szymusiak, H.; Tyrakowska, B.; Zielinski, R.; Soffers, A. E. M. F.; Rietjens, I. M. C. M.; Free Radical Biol. Med. 2001, 31, 869.

11. Pietta, P.; J. Nat. Prod. 2000, 63, 1035.

12. Rosenau, T.; Habicher, W. D.; Tetrahedron 1995, 51, 7919.

13. Hendrickson, H. P.; Kaufman, A.D.; Lunte, C. E.; J. Pharm. Biomed. Anal. 1994, 12, 325.

14. Yang, B.; Kotani, A.; Arai, K.; Kusu, F.; Anal. Sci. 2001, 17, 599.

15. Jorgensen, L. V.; Cornett, C.; Justesen, U.; Skibsted, L. H.; Dragsted, L. O.; Free Radic. Res. 1998, 29, 339.

16. Brett, A. M. O.; Ghica, M. E.; Electroanalysis 2003, 15, 22.
17. Nematollahi, D.; Malakzadeh, M.; J. Electroanal. Chem. 2003, 547, 191

18. Timbola, A. K.; Giacomelli, C.; Pizzolatti, M. G.; Spinelli, A.; Abstracts of the XIII Simpósio Brasileiro de Eletroquímica e Eletroanalítica, Araraquara/SP, Brazil, 2002.

19. Timbola, A. K.; MSc. Dissertation, Universidade Federal de Santa Catarina, Florianópolis/SC, Brazil, 2004.

20. Kissinger, P. T.; Heineman, W. H.; Laboratory Techniques in Electroanalytical Chemistry, $2^{\text {nd }}$ ed., Marcel Decker Inc.: New York, 1996.

21. Bard, A. J.; Faulkner, L. R.; Electrochemical Methods, Fundamentals and Applications, John Wiley \& Sons Inc: New York, 1980.

22. Golabi, S. M.; Nematollahi, D.; J. Electroanal. Chem. 1997, 420, 127.

23. Bodini, M. E.; Copia, G.; Tapia, R.; Leighton, F.; Herrera, L.; Polyhedron 1999, 18, 2233.

24. Awad, H. M.; Boersma, M. G.; Vervoort, J.; Rietjens, I. M. C. M.; Arch. Biochem. Biophys. 2000, 378, 224.

25. Metodiewa, D.; Jaiswal, A. K.; Cenas, N.; Dickancaité, E.; Segura-Aguilar, J.; Free Radical Biol. Med. 1999, 26,107.

26. Smith, M.A.; Webb, R. A; Cline, L. J.; J. Org. Chem. 1965, 30, 995.

27. Solomons, T. W. Graham; Organic Chemistry, John Wiley \& Sons, Inc: New York, 1996.

28. Morrison, R. T.; Boyd, R. N.; Organic Chemistry, New York University, Inc: New Jersey, 1992.

Received: May 13, 2005

Published on the web: December 15, 2005 